\title{
Analisis Kendala Penyelesaian Tindak Lanjut Hasil Pemeriksaan BPK Pada Pemerintah Provinsi Gorontalo
}

\author{
RAHMI RAMADHAN PONGOLIU ${ }^{1}$, DAVID SAERANG ${ }^{2}$, HENDRIK MANOSSOH $^{3}$
}

\author{
${ }^{1,2,3}$ Program Magister Akutansi, Fakultas Ekonomi dan Bisnis Universitas Sam Ratulangi \\ email :amyramadhan@yahoo.com ${ }^{1}$,d_saerang@unsrat.ac.id ${ }^{2}$, hendrik_manossoh@yahoo.com ${ }^{3}$
}

\begin{abstract}
Abstrack. Follow-up audit results is one indicator to determine the successful of an audit process. Law Number 15 of 2004 stipulates that follow-up activities on the recommendation of the audit BPK on Local Government Financial Statement (LKPD) are the responsibility that must be implemented by the entity. Recommendations are improvement on the things that need to be supervised and monitored in order to audit not only limited to giving opinions but more into the financial management improvements that the accountability is aspired to be realized better. Low completion of follow-up on the results of BPK could be an indication that the regional government has not fully committed to implementing the recommendations follow-up given by the examiner. This study is aimed to analyze the obstacles faced by SKPD of Gorontalo Province and the efforts that have been did by the Provincial Government of Gorontalo in order to accelerate the completion of the follow-up audit results of BPK. This study used a qualitative method with case study approach and the Government of Gorontalo Province as the research object with 4 (four) SKPD which is considered to represent the entity of Gorontalo Provincial Government with regard to several factors, namely the completion status of follow-up; the magnitude of the amount managed; the complexity of the activities; public service functions; and the internal audit function. Data was obtained by in-depth interviews, observation and documentation study in 4 (four) SKPD. The key informants were purposively determined to get the right information and accurate based on the following criteria: authoritativeness to the implementation of the follow-up, in charge of finding materials, preparing materials follow-up report, to master the problems of programs and activities, findings related parties, and the internal audit. Results showed that the constraints faced SKPD in following up the audit report of BPK, namely: lack of organizational commitment; weak internal control systems; findings related parties have died/retired/address unknown; rotation of employees; and disagreements over the results of the examination.
\end{abstract}

\section{Keywords: audit findings, financial statements, constraints and efforts of the provincial government, and follow-up}

Abstrak. Tindak lanjut hasil pemeriksaan merupakan salah satu indikator keberhasilan suatu pemeriksaan. Undang-Undang Nomor 15 Tahun 2004 mengamanatkan bahwa kegiatan tindak lanjut atas rekomendasi hasil pemeriksaan BPK atas Laporan Keuangan Pemerintah Daerah (LKPD) merupakan tanggungjawab yang harus dilaksanakan oleh entitas. Rekomendasi merupakan perbaikan terhadap hal yang perlu diawasi dan dimonitoring agar audit yang dilakukan tidak hanya sebatas pemberian opini tetapi lebih kedalam perbaikan pengelolaan keuangan agar akuntabilitas yang dicita-citakan dapat terwujud dengan lebih baik.Rendahnya penyelesaian tindak lanjut rekomendasi hasil pemeriksaan BPK dapat menjadi indikasi bahwa Pemerintah Daerah belum sepenuhnya berkomitmen dalam melaksanakan rekomendasi tindak lanjut yang diberikan oleh pemeriksa.Penelitian ini bertujuan untuk menganalisis kendala-kendala apa saja yang dihadapi oleh SKPD Provinsi Gorontalo serta upaya-upaya yang telah dilakukakan oleh Pemerintah Provinsi Gorontalo dalam rangka percepatan penyelesaian tindak lanjut hasil pemeriksaan BPK. Penelitian ini menggunakan metode kualitatif dengan pendekatan studi kasus dan Pemerintah Provinsi Gorontalo 
sebagai objek penelitian yaitu 4 (empat) SKPD yang dianggap mewakili entitas Pemerintah Provinsi Gorontalo dengan memperhatikan beberapa faktor yaitu status penyelesaian tindak lanjut; besarnya jumlah anggaran yang dikelola; kompleksitas kegiatan; fungsi layanan publik; dan fungsi pengawas internal. Data diperoleh melalui teknik wawancara mendalam, pengamatan, dan studi dokumentasi pada 4 (empat) SKPD. Informan kunci ditentukan secara purposif untuk mendapatkan hasil informasi yang tepat dan akurat berdasarkan kriteria antara lain :mempunyai kewenangan terhadap pelaksanaan tindak lanjut, membidangi materi temuan, menyusun bahan laporan tindak lanjut, menguasai permasalahan program dan kegiatan, pihak terkait temuan, dan pengawas internal. Hasil penelitian menunjukkan adanya kendala-kendala yang dihadapi SKPD dalam menindaklanjuti hasil pemeriksaan BPK yaitu : (1) kurangnya komitmen organisasional; (2) lemahnya sistem pengendalian intern; (3) pihak terkait temuan telah meninggal/pensiun/alamat tidak diketahui; (4) rotasi pegawai; dan (5) adanya ketidaksepakatan atas hasil pemeriksaan.

Kata Kunci : hasil pemeriksaan, laporan keuangan,kendala dan upaya pemerintah provinsi, dan tindak lanjut

\section{Pendahuluan}

Undang-Undang Nomor 23 Tahun 2014 tentang Pemerintahan Daerah dan UU Nomor 33 Tahun 2004 tentang Perimbangan Keuangan antara Pemerintah Pusat dan Pemerintah Daerah menyatakan bahwa Keuangan Daerah haruslah dikelola secara tertib, taat pada peraturan perundang-undangan, efisien, ekonomis, efektif, transparan, dan bertanggung jawab dengan memperhatikan keadilan, kepatutan, dan manfaat untuk masyarakat. Dalam hal pertanggungjawaban terhadap pengelolaan keuangan tersebut, Pemerintah Provinsi/Kabupaten/Kota menyusun Laporan Keuangan Pemerintah Daerah (LKPD) yang diperiksa oleh Badan Pemeriksa Keuangan (BPK).

Tindak lanjut hasil pemeriksaan merupakan rekomendasi dari BPK yang harus dilaksanakan oleh Pemerintah Daerah dalam rangka meningkatkan akuntabilitas pengelolaan keuangan tahun selanjutnya. Semakin baik pemerintah melaksanakan penyelesaian tindak lanjut rekomendasi hasil pemeriksaan maka semakin baik pula akuntabilitas pengelolaan keuangannya, yang ditunjukkan dengan semakin sedikitnya temuan terhadap pemeriksaan pada tahun selanjutnya.

Dalam pelaksanaannya, tindak lanjut hasil pemeriksaan BPK pada setiap instansi pemerintah merupakan tanggungjawab yang harus dilakukan oleh pejabat pada instansi tersebut. Dimana pejabat diberikan waktu untuk memberikan jawaban atau penjelasan tentang tindak lanjut atas rekomendasi dalam pemeriksaan kepada BPK selambat-lambatnya 60 (enam puluh) hari setelah laporan hasil pemeriksaan diterima. Jika dalam waktu yang telah ditentukan pejabat diketahui belum melaksanakan kewajibannya tersebut, maka kepada yang bersangkutan dapat dikenai sanksi administratif sesuai dengan ketentuan perundang-undangan di bidang kepegawaian (UU Nomor 15 Tahun 2004).

Penyelesaian tindak lanjut hasil pemeriksaan adalah salah satu indikator kunci dari kinerja pengawasan. Kegagalan dalam pelaksanaan tindak lanjut hasil pemeriksaan harus disadari adalah sebagai pemborosan keuangan negara, maka penyelesaiannya seharusnya menjadi kewajiban dan tanggungjawab bukan hanya oleh pejabat melainkan juga oleh seluruh pihak terkait. Sehubungan dengan itu, BPK perlu memantau dan menginformasikan hasil pemantauan atas tindak lanjut tersebut kepada DPRD.

Penyelesaian tindak lanjut rekomendasi hasil pemeriksaan BPK oleh Pemerintah Provinsi Gorontalo masih menunjukkan persentase yang cukup rendah. Hal ini terlihat pada masih banyaknya rekomendasi yang belum sesuai atau dalam proses tindak lanjut dan belum ditindaklanjuti. Rendahnya penyelesaian tindak lanjut rekomendasi hasil pemeriksaan BPK dapat menjadi indikasi bahwa Pemerintah Daerah belum sepenuhnya berkomitmen dalam melaksanakan rekomendasi tindak lanjut yang diberikan oleh pemeriksa.

Secara kumulatif, penyelesaian rekomendasi hasil pemeriksaan BPK sampai dengan akhir semester I tahun 2016 pada Pemerintah Provinsi Gorontalo masih cukup rendah. Hal ini terlihat pada masih banyaknya rekomendasi yang belum sesuai atau dalam proses tindak lanjut dan belum ditindaklanjuti. Rendahnya penyelesaian tindak lanjut rekomendasi hasil pemeriksaan BPK dapat 
menjadi indikasi bahwa Pemerintah Daerah belum sepenuhnya berkomitmen dalam melaksanakan rekomendasi tindak lanjut yang diberikan oleh pemeriksa. Dengan menindaklanjuti hasil rekomendasi BPK, maka Pemerintah Provinsi Gorontalo dapat memperbaiki temuan-temuan periode sebelumnya sehingga mengurangi temuan-temuan pada periode selanjutnya.

Penelitian tentang tindak lanjut hasil pemeriksaan belum banyak dilakukan. Setyaningrum, et al (2014) dalam penelitiannya menunjukkan bahwa semakin banyak rekomendasi BPK yang ditindaklanjuti sesuai rekomendasi akan meningkatkan kualitas laporan keuangan yang direpresentasikan dari tingkat pengungkapan yang tinggi. Selain itu, Lin dan Liu (2012) dalam penelitiannya menyatakan bahwa temuan yang dilaporkan kepada auditan harus diikuti dengan meminta pertanggungjawaban dari auditan serta melakukan langkah perbaikan. Apabila rekomendasi tersebut telah ditindaklanjuti secara nyata dan tuntas oleh pejabat yang diperiksa sesuai dengan rekomendasi BPK, diharapkan dapat memperbaiki pengelolaan dan tanggung jawab keuangan pada Pemerintah Provinsi Gorontalo (BPK, 2015). Dengan menindaklanjuti hasil rekomendasi BPK, maka Pemerintah Provinsi Gorontalo dapat memperbaiki temuan-temuan periode sebelumnya sehingga mengurangi temuan-temuan pada periode selanjutnya.

Tujuan yang ingin dicapai dalam penelitian ini adalah untuk menganalisis kendala-kendala apa saja yang dihadapi oleh SKPD dan upaya-upaya apa yang telah dilakukan oleh Pemerintah Provinsi Gorontalo dalam rangka percepatan penyelesaian tindak lanjut hasil pemeriksaan BPK.

\section{Kerangka Konseptual Penelitian}

Kerangka konseptual dalam penelitian ini berdasarkan latar belakang masalah yang terjadi pada Pemerintah Provinsi Gorontalo, dimana tindak lanjut hasil pemeriksaan BPK mengalami kendala dalam penyelesaiannya oleh SKPD yang antara lain disebabkan oleh : kurangnya komitmen organisasional pada satuan/unit kerja, Adanya temuan berulang yang disebabkan oleh belum terbangunnya Sistem Pengendalian Internal (SPI) yang andal dalam satuan/unit kerja, lemahnya sanksi bagi pimpinan satuan/unit kerja atau pihak terkait temuan yang lambat dalam menyelesaikan tindak lanjut hasil pemeriksaan, belum efektifnya monitoring atau evaluasi terhadap temuan yang belum ditindaklanjuti, dan kurangnya koordinasi antara pemeriksa dengan auditan mengenai hasil pemeriksaan.

\section{Metode Penelitian}

Penelitian ini menggunakan metode penelitian kualitatif dengan pendekatan studi kasus (case study). John W. Creswell (2008) menyatakan bahwa studi kasus merupakan strategi penelitian di mana di dalamnya peneliti menyelidiki secara cermat suatu program, peristiwa, aktivitas, proses, atau sekelompok individu. Kasus-kasus dibatasi oleh waktu dan aktivitas, dan peneliti mengumpulkan informasi secara lengkap dengan menggunakan berbagai prosedur pengumpulan data berdasarkan waktu yang telah ditentukan. Ditinjau dari wilayahnya, maka penelitian kasus hanya meliputi daerah atau subyek yang sangat sempit. Tetapi ditinjau dari sifat penelitian, penelitian kasus lebih mendalam.

Pendekatan studi kasus ini diambil sebagai disain penelitian oleh peneliti untuk menyelidiki secara cermat, intensif terinci dan mendalam terhadap aktivitas dan proses tindak lanjut hasil pemeriksaan BPK yang dilaksanakan oleh SKPD Provinsi Gorontalo dengan mengumpulkan informasi secara lengkap dengan menggunakan berbagai prosedur pengumpulan data berdasarkan periode tertentu.

Teknik pengumpulan data yang dilakukan dalam penelitian ini adalah melalui pengamatan/observasi(observation), wawancara mendalam (indepth interview), dan dokumentasi (documentation) .Selan-jutnya, uji keabsahan data dalam penelitian kualitatif meliputi uji validitas internal (credibility), uji validitas eksternal (transferability), uji reliabilitas (dependability), dan uji objektivitas (confirmability).

Metode analisis data yang dipakai adalah analisis interaktif (interactive analysis) dengan menggunakan interview transcription yang di-transcribe dari hasil wawancara untuk menganalisis data. Langkah selanjutnya aktivitas analisis data Miles and Huberman (1984) dalam Herdiansyah (2010) terdiri atas: data reduction, data display dan conclusion drawing/verification yang dilakukan 
secara interaktif dan berlangsung secara terus menerus sampai tuntas, sehingga datanya mencapai jenuh. Analisis data yang dikembangkan pada penelitian ini adalah dengan editing, kategorisasi/coding dan meaning(Musfiqon, 2012).

\section{Analisis dan Pembahasan}

Penelitian ini dilakukan selama 3 (tiga) bulan yakni antara bulan November 2016 hingga bulan Januari 2017. Intrumen penelitian pendukung adalah buku catatan (notebook), pedoman wawancara, instru-men observasi lapangan, alat perekam berupa audio recorder untuk merekam pelaksanaan wawancara dengan informan yang hasilnya di-transcribe menjadi transkrip data, kamera untuk mendokumentasikan kegiatan penelitian dilapangan, laptop untuk menunjang penulisan hasil penelitian dan ditunjang pengalaman peneliti sebagai pegawai pada Inspektorat Provinsi Gorontalo selama 6 (enam) tahun.

\section{Kendala Penyelesaian Tindak Lanjut}

Kegiatan penanganan tindak lanjut temuan hasil pemeriksaan merupakan upaya untuk menyelesaikan tindak lanjut atas rekomendasi yang tercantum dalam LHP BPK. Dalam proses penyelesaian tindak lanjut hasil pemeriksaan, maka Kepala SKPD sebagai pimpinan puncak harus memiliki komitmen yang kuat terhadap hasil pemeriksaan dan pemahaman mengenai arti pentingnya kegiatan pemeriksaan yang kemudian direspon dengan baik oleh bawahan dalam rangka peningkatan kinerja SKPD.

Kegiatan tindak lanjut merupakan tanggung jawab pejabat yang berwenang. Hasil penelitian yang dilakukan dengan wawancara dengan SKPD menyampaikan bahwa derajat komitmen pejabat yang ada di SKPD kurang maksimal, sehingga langkah-langkah konkrit dalam penyelesaian tindak lanjut pun dinilai kurang optimal. Untuk itu dibutuhkan pejabat eselon 3 dan 4 yang andal sebagai penanggungjawab pelaksanaan kegiatan di SKPD. Lebih lanjut, kendala yang dihadapi dalam penyelesaian tindak lanjut hasil pemeriksaan BPK adalah karena tidak tertanganinya dengan baik masalah ini segera setelah hasil pemeriksaan diberikan kepada SKPD.

Meskipun sanksi berdasarkan Undang-Undang Nomor 15 Tahun 2004 telah ditegaskan bahwa Pejabat Negara wajib menindaklanjuti rekomendasi dalam laporan hasil pemeriksaan (pasal 20 ayat 1), dapat dikenakan sanksi administratif, (pasal 20 ayat 5) dan pasal 26 ayat (2) setiap orang yang tidak memenuhi kewajiban menindaklanjuti rekomendasi akan dipidana penjara paling lama

satu tahun enam bulan dan/atau denda paling banyak lima ratus juta rupiah, namun sanksi tersebut belum disadari dan dipahami oleh pimpinan unit kerja. Tidak tertanganinya dengan baik penyelesaian tindak lanjut hasil pemeriksaan ini merupakan salah satu faktor yang disebabkan oleh kurangnya komitmen dari pejabat yang berwenang di SKPD.

Hasil wawancara dengan informan menunjukkan bahwa pejabat yang ada di SKPD dan ASN terkait temuan belum sepenuhnya berkomitmen terhadap penyelesaian tindak lanjut hasil pemeriksaan BPK. Dalam rangka mendukung pelaksanaan tindak lanjut, butuh komitmen kuat dari pimpinan SKPD maupun pemda untuk mendorong aparatur di bawahnya agar serius menindaklanjuti rekomendasi BPK. Meyer dan Ellen dalam Khaerul Umam (2010) merumuskan suatu definisi mengenai komitmen organisasional (organizationalcCommitment) sebagai suatu keadaan dimana individu memiliki kepercayaan, keterikatan, serta perasaan memiliki atas organisasi sehingga individu tersebut akan lebih mengutamakan kepentingan organisasi dibandingkan kepentingan individu yang ditandai dengan bentuk loyalitas dan identifikasi diri terhadap organisasi. Sedangkan Robbins (2007) mengemukakan bahwa sebagian besar penelitian difokuskan pada tiga sikap yaitu kepuasan kerja, keterlibatan pekerjaan dan komitmen organisasional.

Lebih lanjut, Moon (2003) dalam penelitiannya menunjukkan bahwa pada perusahaan public yang melayani kepentingan masyarakat luas sangat diperlukan komitmen organisasi yang tinggi dari anggotanya. Sedangkan Meyer (2003) menyatakan bahwa terdapat pengaruh positif antara komitmen karyawan terhadap organisasi dengan peningkatan kinerja karyawan yang bersangkutan.

Kegiatan tindak lanjut hasil pemeriksaan merupakan hal penting yang harus segera dilakukan oleh auditan guna membantu merealisasikan tujuan dan kelangsungan organisasi serta mendorong tercapainya kinerja SKPD yang lebih baik. Karena ketika rekomendasi yang lama belum selesai ditindaklanjuti, BPK akan mengeluarkan rekomendasi baru atas hasil audit yang baru sehingga 
rekomendasinya akan menumpuk-numpuk. Untuk itu dibutuhkan komitmen yang kuat bukan hanya oleh pimpinan namun seluruh unsur yang ada di SKPD. Hal ini seperti yang diungkapkan oleh Yuwono (2005) yang menyatakan bahwa komitmen pada organisasi tidak hanya menyangkut kesetiaan karyawan pada organisasi yang bersifat positif tetapi juga melibatkan hubungan yang aktif dengan organisasi, dimana karyawan bersedia atas kemauan sendiri untuk memberikan segala sesuatu yang ada pada dirinya guna membantu merealisasikan tujuan dan kelangsungan organisasi.

Kendala Penyelesaian tindak lanjut lainnya yang dihadapi oleh SKPD yaitu lemahnya Sistem Pengendalian Internal (SPI). SPI adalah proses yang integral pada tindakan dan kegiatan yang dilakukan secara terus menerus oleh pimpinan dan seluruh pegawai untuk memberikan keyakinan memadai atas tercapainya tujuan organisasi melalui kegiatan yang efektif dan efisien, keandalan pelaporan keuangan, pengamanan aset Negara, dan ketaatan terhadap peraturan perundangundangan (Moeler, 2009).

Hasil wawancara dengan informan menunjukkan masih rendahnya penegakan integritas yang ada di Pemerintah Provinsi Gorontalo, dimana pihak terkait temuan tidak serius, kurang perhatian, dan kurang bertanggungjawab untuk menindaklanjuti hasil pemeriksaan BPK. Hal ini dapat disebabkan antara lain karena lingkungan pengendalian yang masih lemah sehingga unsur-unsur yang ada didalamnya tidak bisa mengaplikasikan dengan baik sesuai kebijakan, prosedur, dan peraturan yang berlaku. Lingkungan pengendalian akan efektif bila suatu lingkungan dengan orangorang yang berkompeten memahami tanggungjawabnya, batasan kewenangannya, memiliki pengetahuan yang memadai, memiliki kesadaran yang penuh, dan komitmen untuk melakukan apa yang benar dan yang seharusnya. Peranan pimpinan dalam unsur ini sangat penting, dan manajemen bertanggungjawab untuk mendorong penerapan tingkat integritas dalam organisasi.

Pemerintah Provinsi Gorontalo telah menetapkan aturan atau standar perilaku yang memberikan kerangka perilaku bagi pegawai yang tertuang dalam Pakta Integritas. Namun pada kenyataannya, masih terdapat penyimpangan terhadap pelaksanaan kegiatan yang disebabkan oleh individu yang dinilai kurang memiliki integritas sehingga temuan pemeriksaan terus saja terjadi. Hal ini mencerminkan bahwa individu yang ada dalam organisasi belum sepenuhnya melaksanakan sesuai dengan apa yang telah disepakati dalam Pakta Integritas.

Langkah konkrit yang dapat direkomendasikan dalam mengatasi masalah ini yaitu pimpinan instansi dan seluruh pegawai harus menciptakan dan memelihara lingkungan dalam keseluruhan organisasi yang menimbulkan perilaku positif dan mendukung terhadap pengendalian intern dan manajemen yang sehat melalui penegakan integritas dan nilai etika. Dalam kondisi pegawai tidak memenuhi kebijakan dan prosedur tersebut termasuk standar prilaku, pimpinan organisasi harus mengambil tindakan disiplin yang tegas sesuai dengan ketentuan yang berlaku guna mempertahankan lingkungan pengendalian yang efektif.

Evaluasi terhadap efektivitas sistem pengendalian dalam organisasi perlu terus dilakukan oleh pimpinan agar tidak terjadi lagi penyimpangan yang memunculkan temuan yang sama, sehingga kegiatan tindak lanjut dapat dilaksanakan ssesuai dengan waktu yang telah ditentukan. Menurut COSO (2000) menyatakan bahwa manajemen perlu secara terus menerus menilai dan mengevaluasi sistem pengendalian manajemen untuk memastikan bahwa sistem pengendalian telah dirancang dan beroperasi secara baik, dimutakhirkan secara tepat untuk mengantisipasi perubahan kondisi dan lingkungan, dan pada akhirnya memastikan pencapaian tujuan organisasi.

Berdasarkan hasil wawancara diatas maka dapat disimpulkan bahwa Pemerintah Provinsi Gorontalo belum sepenuhnya merancang dan melaksanakan unsur-unsur sistem pengendalian intern sebagaimana yang dipersyaratkan dalam peraturan perundang-undangan. Dengan melihat pentingnya peran SPI dalam rangka mencapai tujuan dan sasaran organisasi serta untuk mewujudkan tata kelola pemerintahan yang baik maka pimpinan SKPD harus dapat menjadikan penerapan SPI menjadi tanggung jawab bersama tidak hanya pada unit kerja terkecil tapi hingga kepada masingmasing individu. Menurut Weygandt, et al. (2007) bahwa prinsip-prinsip pengendalian internal meliputi pembentukan tanggung jawab, pemisahan tugas, prosedur dokumentasi, pengendalian fisik, mekanik dan elektronik, verifikasi internal independent dan pengendalian lainnya.

Selanjutnya Kendala yang dihadapi oleh SKPD yaitu pihak terkait temuan telah pensiun/meninggal /tidak diketahui alamatnya. Setiap kerugian Negara/Daerah yang disebabkan oleh tindakan melanggar hukum atau kelalaian seseorang, wajib segera diselesaikan sesuai ketentuan 
peraturan perundang-undangan yang berlaku. Begitupun halnya dengan bendahara, pegawai negeri bukan bendahara, pejabat lain, atau pihak ketiga yang karena perbuatannya melanggar hukum atau melalaikan kewajiban yang dibebankan kepadanya secara langsung merugikan keuangan Negara/Daerah, wajib menggantikan kerugian tersebut. Rekomendasi yang diberikan oleh auditor merupakan langkah yang harus segera dilakukan setelah hasil pemeriksaan diterima karena rekomendasi diberikan dengan tujuan untuk perbaikan kinerja organisasi kedepannya. Audit secara formal memberikan rekomendasi-rekomendasi untuk perbaikan kinerja di masa datang Mardiasmo (2009). yang didasarkan pada temuan-temuan selama proses audit. Rekomendasi yang diberikan auditor perlu segera ditindaklanjuti oleh pihak-pihak yang berwenang agar perbaikan kinerja dapat segera mungkin dilaksanakan.

Permasalahan rotasi pegawai atau mutasi (transfer) merupakan kendala penyelesaian tindak lanjut yang terjadi pada internal SKPD Provinsi Gorontalo. Masalah yang paling sering muncul yaitu sulitnya penanganan tindak lanjut bagi pejabat/ASN terkait temuan yang telah ditugaskan ke SKPD lain, Namun rotasi pegawai ini tidak bisa dihindarkan harus terjadi pada organisasi karena organisasi pada umumnya melakukan mutasi pegawai atas dasar pertimbangan : penyegaran yang dimaksudkan agar tidak terjadi kejenuhan atas pekerjaan yang telah dijalani selama bertahun-tahun; kompetensi yang dimaksudkan agar penempatan karyawan didasari pengetahuan dan keahlian yang dimilikinya; dan reorganisasi karena perusahaan melakukan perampingan atau perluasan usaha sehingga perlu promosi dan mutasi sesuai dengan kebutuhan.

Untuk mengatasi hal ini, maka Pemerintah Provinsi Gorontalo perlu membentuk Satgas tindak lanjut pada masing-masing SKPD yang bertujuan melaksanakan kegiatan tindak lanjut mulai dari pendokumentasian agar penyelesaian tindak lanjut hasil pemeriksaan dapat dilaksanakan sesuai dengan rekomendasi yang diberikan dan tepat pada waktu yang telah ditetapkan. Purba (2013) dalam penelitiannya menyatakan bahwa keberhasilan satuan tugas yang menangani kegiatan tindak lanjut pemeriksaan BPK ini sangat penting dan menjadi tolak ukur keberhasilan PEMDA terkait dalam merespon dengan baik rekomendasi BPK.

Kendala selanjutnya yang dihadapi SKPD yaitu adanya ketidaksepakatan atas hasil pemeriksaan. Pemeriksaan BPK dilaksanakan dengan menggunakan standar pemeriksaan keuangan Negara. Namun dalam pelaksanaannya masih terdapat hasil pemeriksaan yang tidak disepakati atau diakui sebagai temuan oleh auditan.

Adanya ketidaksepakatan hasil pemeriksaan dapat terjadi karena auditor kurang cermat dan kurang memiliki kualitas teknis dan profesi yang diperlukan untuk melaksanakan tugas pemeriksaan. Akmal (2007) menyatakan bahwa auditor internal diharuskan memahami standar profesi secara keseluruhan secara mendalam. Kemahiran profesional auditor yang cermat dan seksama menunjukkan kepada pertimbangan profesional (professional judgement) yang dilakukan auditor selama pemeriksaan. Hal ini mengindikasikan bahwa penggunaan kemahiran profesional auditor yang cermat dan seksama (due professional care) akan berdampak terhadap baik atau tidaknya kualitas audit (Sinamora, 2009). Indra Bastian (2010) menyatakan bahwa audit internal yang memiliki kecakapan teknis dan keahlian profesional akan menghasilkan laporan yang berkualitas.

Kemampuan profesional merupakan salah satu kriteria profesionalisme auditor internal dalam SPAI menurut konsorsium Organisasi Profesi Audit Internal (2004), dimana internal auditor harus mencerminkan keahlian dan ketelitian profesional sebagai berikut : (1) Kesesuaian dengan standar profesi, internal auditor harus mematuhi standar profesional dalam melaksanakan pemeriksaan; (2) Pengetahuan dan kecakapan, internal auditor harus memiliki dan mendapatkan pengetahuan, kecakapan dan disiplin ilmu yang penting dalam melaksanakan pemeriksaan; (3) Hubungan antar manusia dan komunikasi; internal auditor haus memiliki kemampuan untuk menghadapi orang lain dan berkomunikasi secara efektif; dan (4) Pendidikan berkelanjutan; internal auditor harus mengembangkan kemampuan melalui pendidikan yang berkelanjutan. Ketelitian profesional; internal auditor harus bertindak dengan ketelitian profesional yang sepatutnya.

\section{Upaya Percepatan Penyelesaian Tindak Lanjut}

Penyelesaian tindak lanjut hasil pemeriksaan merupakan kewajiban yang harus dilaksanakan oleh Pemerintah Provinsi Gorontalo. Upaya percepatan penyelesaian tindak lanjut hasil pemeriksaan 
BPK Pemerintah Gorontalo dilaksanakan oleh Inspektorat yang berfungsi sebagai pengawas internal Pemerintah Provinsi Gorontalo. Pelaksanaan tindak lanjut rekomendasi hasil pemeriksaan BPK di Provinsi Gorontalo diawasi oleh Inspektorat selaku auditor internal. Inspektorat memiliki peran yang sama dengan auditor internal dalam perusahaan yang dapat mengurangi fraud atau kesalahan dalam penyajian laporan keuangan untuk tahun berikutnya (Abbot dan Parker, 2002 dalam Hartanto, 2015).

Upaya yang dilakukan oleh Pemerintah Provinsi Gorontalo yaitu : pertama, peningkatan Komitmen Dalam Penyelesaian Tindak Lanjut Hasil Pemeriksaan. Setiap manajemen dari suatu organisasi pasti dituntut untuk menaikkan pertumbuhan atau kemajuan yang lebih baik dari waktu ke waktu. Untuk mendukung semua itu, butuh komitmen dari pimpinan puncak (top management). Edison, et al (2016) menyatakan bahwa komitmen merupakan tekad dari pengambil keputusan dalam mencapai tujuan-tujuan yang telah ditetapkan. Sedangkan Sidik Priadana (2012) menyatakan bahwa tidak cukup dengan komitmen saja, perlu konsensus, konsistensi dan konsekuensi dalam mengimplementasikan rencana strategis yang sudah dibuat.

Dapat disimpulkan bahwa dengan melihat penyelesaian tindak lanjut hasil pemeriksaan BPK yang ada saat ini, langkah konkrit yang dapat direkomendasikan untuk Pemerintah Provinsi Gorontalo yaitu melakukan evaluasi sejauh mana hasil yang telah dicapai setelah pemberian sanksi tersebut dilaksanakan. Sehingga dapat diketahui apakah komitmen yang dibangun memiliki daya dorong untuk tercapainya penyelesaian tindak lanjut hasil pemeriksaan BPK.

Kedua, memaksimalkan fungsi pengawasan. Fungsi pengawasan terhadap penyelenggaraan Pemerintahan Provinsi Gorontalo dilaksanakan oleh Inspektorat. Dalam rangka meningkatkan fungsi ini, Inspektorat merumuskan kebijaksanaan teknis di bidang pengawasan; menyusun rencana dan program di bidang pengawasan; melaksanakan pengendalian teknis operasional pengawasan; dan melaksanakan koordinasi pengawasan dan tindak lanjut.

Berdasarkan hasil wawancara diatas dapat disimpulkan bahwa Pemerintah Provinsi Gorontalo melalui Inspektorat telah melaksanakan fungsi pengawasan terhadap penyelenggaraan pemerintahan dalam upaya percepatan penyelesaian tindak lanjut hasil pemeriksaan BPK. Dalam pengawasan tersebut, Inspektorat dituntut untuk dapat melaksanakan fungsinya dalam rangka pencapaian tujuan organisasi serta dapat memberikan informasi mengenai kehematan, efisiensi dan efektifitas pelaksanaan kegiatan pada seluruh instansi yang ada di Provinsi Gorontalo. Pentingnya pengawasan internal ini seperti yang diungkapkan oleh Sawyer et al (2006) yang menyatakan bahwa audit internal bertindak sebagai penilai independen untuk menelaah operasional organisasi dengan mengukur dan mengevaluasi kecukupan kontrol serta efisiensi dan efektivitas kinerja organisasi. Dimana audit tersebut dapat membantu organisasi mencapai tujuannya dengan menerapkan pendekatan yang sistematis dan berdisiplin untuk mengevaluasi dan meningkatkan efektivitas proses pengelolaan risiko, kecukupan kontrol dan pengelolaan organisasi.

Pengawasan yang dilakukan oleh Inspektorat Provinsi Gorontalo yang dimulai dari perencanaan kegiatan hingga pelaporan oleh instansi yang ada di Pemerintah Provinsi Gorontalo merupakan upaya menuju terwujudnya pemerintahan yang baik dan bersih (good govenment and clean government). Peran ini diharapkan mampu menjadi Early Warning System (peringatan dini) bagi seluruh instansi agar tata kelola pemerintahan yang baik dan bersih dapat tercapai yang selanjutnya akan meminimalisir temuan-temuan BPK.

Ketiga, melakukan evaluasi dan monitoring terhadap Tindak Lanjut Hasil Pemeriksaan secara berkala. Berdasarkan hasil wawancara diatas dapat disimpulkan bahwa kegiatan monitoring dan evaluasi yang dilakukan oleh Inspektorat Provinsi Gorontalo merupakan upaya untuk menindaklanjuti Sidang Majelis Pertimbangan TP-TGR. Monitoring dan evaluasi merupakan bagian dari kegiatan pemantauan pengendalian intern dalam salah satu unsur SPIP. Kegiatan pemantauan bertujuan untuk memastikan apakah sistem pengendalian intern pada suatu instansi pemerintah telah berjalan sebagaimana yang diharapkan dan apakah perbaikan-perbaikan yang perlu dilakukan telah dilaksanakan sesuai dengan perkembangan yang terjadi. Pemantauan memungkinkan identifikasi dan koreksi atas kekurangan-kekurangan yang terjadi pada sistem pengendalian sebelum hal-hal tersebut mempengaruhi secara material terhadap pencapaian tujuan organisasi (BPKP, 2009).

Kegiatan pemantauan yang dilakukan oleh Inspektorat Provinsi Gorontalo mencakup kebijakan dan prosedur untuk memastikan bahwa semua temuan dan rekomendasi audit telah diperhatikan dan segera ditindaklanjuti oleh pimpinan instansi. Penyelesaian tindak lanjut rekomendasi hasil 
pemeriksaan merupakan upaya untuk memastikan bahwa temuan dan reviu lainnya telah atau segera diselesaikan.

Secara keseluruhan dari hasil analisis diatas menunjukkan bahwa penyelesaian tindak lanjut merupakan salah satu kriteria untuk penilaian kinerja Pemerintah Provinsi Gorontalo, sehingga sangat berpengaruh pada kinerja tahun selanjutnya. Apabila rekomendasi tersebut telah ditindaklanjuti secara nyata dan tuntas oleh pejabat yang diperiksa sesuai dengan rekomendasi BPK, diharapkan dapat memperbaiki pengelolaan dan tanggung jawab keuangan Negara pada Pemerintah Provinsi Gorontalo (BPK, 2015). Untuk itu dibutuhkan komitmen yang tinggi dari seluruh unsur yang ada di SKPD Provinsi Gorontalo serta dukungan dari Inspektorat dalam mengawal percepatan penyelesaiannya. Disamping itu, dengan adanya batasan waktu penyelesaian temuan hasil pemeriksaan BPK yaitu 60 hari kerja setelah LHP diterima, maka perlu dilakukan koordinasi intensif dalam rangka penanganan dan penyelesaian tindak lanjut tersebut sehingga bisa diselesaikan sebelum batas waktu yang ditentukan. Hasil penelitian Sari, Martani \& Setyaningrum (2014) menunjukkan semakin banyak rekomendasi BPK yang ditindaklanjuti sesuai rekomendasi akan meningkatkan kualitas laporan keuangan yang direpresentasikan dari tingkat pengungkapan yang tinggi.

\section{Penutup}

Kesimpulan penelitian ini bahwa kendala-kendala yang dihadapi SKPD Provinsi Gorontalo dalam penyelesaian tindak lanjut hasil pemeriksaan BPK adalah : (1) Pejabat/ASN terkait temuan belum sepenuhnya berkomitmen terhadap penyelesaian tindak lanjut hasil pemeriksaan BPK, sehingga penyelesaiannya menjadi berlarut-larut karena tidak segera dilaksanakan pada saat hasil pemeriksaan diketahui. Dalam rangka mendukung tindak lanjut butuh komitmen kuat dari pimpinan SKPD maupun Pemda untuk mendorong aparatur di bawahnya agar serius menindaklanjuti rekomendasi BPK. (2) Lemahnya pengendalian internal SKPD, Tim SPI belum optimal dalam melakukan pengendalian dan pengawasan sehingga kejadian-kejadian yang sama terulang kembali pada pelaksanaan APBD tahun berikutnya. Hal ini berdampak pada pemulihan atas kasus-kasus kerugian daerah yang belum ditindaklanjuti Pemerintah Provinsi Gorontalo tidak dapat segera dilaksanakan. (3) Pihak terkait temuan sudah mutasi/pensiun/meninggal dunia dan yang terkait dengan pihak ketiga yaitu perusahaan telah non aktif serta alamat tidak diketahui lagi. (4) Pengembalian kerugian Negara/Daerah belum dilaksanakan secara maksimal oleh SKPD. (5) Rotasi pegawai pada Pemerintah Provinsi Gorontalo berdampak pada kelambanan penanganan tindak lanjut hasil pemeriksaan BPK. (6) Adanya ketidaksepakatan atas hasil pemeriksaan yang berdampak pada berlarut-larutnya temuan yang tidak dapat ditindaklanjuti karena penghapusan temuan oleh BPK harus melalui proses yang cukup lama.

Adapun upaya-upaya yang telah dilakukan oleh Pemerintah Provinsi Gorontalo dalam rangka percepatan penyelesaian tindak lanjut hasil pemeriksaan BPK adalah : (1) Komitmen terhadap percepatan penyelesaian tindak lanjut hasil pemeriksaan melalui koordinasi antara Baperjakat dengan Inspektorat terkait pengenaan sangsi administratif berupa pemberhentian dari jabatan bagi pejabat yang lambat dalam menyelesaikan tindak lanjut hasil pemeriksaan. (2) Meningkatkan fungsi pengawasan internal melalui program dan kegiatan pengawasan oleh Inspektorat diantaranya yaitu : Probity Audit; Evaluasi SPIP; Kerjasama TP4D dengan Kejaksaan untuk mengawal mengamankan dan mendukung keberhasilan pemerintahan dan pembangunan melalui upaya-upaya pencegahan preventif dan persuasif; aktif melaksanakan Sidang Majelis Pertimbangan Tuntutan Perbendaharaan dan Tuntutan Ganti Rugi (MP TP-TGR) yang didalamnya terdapat Tim Penyelesaian Kerugian Negara/Daerah (TPKND); telah membuat mekanisme baku/standar yang berkaitan dengan proses penyelesaian tindak lanjut atas rekomendasi hasil pemeriksaan yang dituangkan dalam Pergub dan SOP penyelesaian tindak lanjut hasil pemeriksaan; dan membuat rancangan Perda tentang Tuntutan Ganti Kerugian Negara/Daerah. (4) Melakukan kegiatan pemantauan melalui monitoring dan evaluasi tindak lanjut hasil pemeriksaan dengan seluruh SKPD terkait temuan secara berkala setiap bulan.

Saran yang dapat diberikan dari penelitian ini : (1) Pemerintah Provinsi Gorontalo perlu mendorong terwujudnya tata kelola keuangan yang transparan dan akuntabel melalui percepatan penyelesaian tindak lanjut hasil pemeriksaan BPK. (2) Pemerintah Provinsi Gorontalo perlu 
meningkatkan komitmen dalam bentuk pemberian sangsi yang lebih tegas sesuai peraturan perundang-undangan yang berlaku bagi pejabat yang lambat dalam melaksanakan penyelesaian tindak lanjut hasil pemeriksaan BPK. (3) SKPD Provinsi Gorontalo perlu menetapkan prosedur formal dalam bentuk SOP sebagai pedoman melaksanakan tugas dan tanggung jawab serta melaksanakan dengan sebaik-baiknya sesuai pedoman yang telah ditetapkan. (4) Pimpinan SKPD selaku Pengguna Anggaran harus lebih meningkatkan pengawasan terhadap pelaksanaan pekerjaan fisik di lapangan agar temuan tidak semakin menumpuk. (5) Pemerintah Provinsi perlu membuat SK Pencatatan untuk pegawai bukan bendahara dan pejabat lain yang telah pensiun/meninggal/dan atau tidak diketahui lagi alamatnya untuk dimasukkan ke dalam kategori temuan yang tidak dapat ditindaklanjuti. (6) Melakukan penatausahaan administrasi terkait penyelesaian tindak lanjut hasil pemeriksaan secara tertib dan lengkap agar memudahkan SKPD dalam menangani penyelesaian tindak lanjut walaupun terjadi rotasi pegawai. (7) Meningkatkan koordinasi antara auditan dengan auditor sekaligus menyamakan pemahaman terhadap hasil pemeriksaan, sehingga solusi terhadap temuan-temuan yang sulit ditindaklanjuti dapat segera dicapai. (8) Membentuk tim satgas percepatan penyelesaian tindak lanjut pada masing-masing SKPD agar setiap hasil pemeriksaan dapat ditangani dengan baik hingga tuntas sesuai dengan jangka waktu penyelesaian yang ditentukan. (9) Melakukan pemantauan oleh satgas pada tiap SKPD secara berkala dan pembahasan tindak lanjut rekomendasi bersama BPK minimal setiap 3 bulan. (10) Penguatan peran APIP bukan hanya didasarkan atas banyaknya temuan yang diperoleh auditor atau besarnya pengembalian ke kas Negara/Daerah, namun harus dapat memerankan perannya sebagai "early warning system" atau bisa mengurangi tingkat penyimpangan dengan memberikan peringatan lebih dini. (11) Untuk peneliti selanjutnya agar meneliti lebih dalam mengenai : (1) kemampuan profesional auditor BPK dalam melaksanakan pemeriksaan; dan (2) Fungsi pengawasan oleh DPRD dalam menindaklanjuti hasil pemeriksaan BPK.

\section{Daftar Pustaka}

Abbott, L.J., Parker, S., dan Peters, G.F. 2002. Audit Committee Characteristics and Restatement. Auditing : A Journal of Practice and Theory. Vol. 23 No. 1: 69-87

Akmal. 2006. Pemeriksaan Intern (Internal Audit). Jakarta : PT Indeks.

Arens, Alvin A; Randal J. Elder and Mark S. Beasley. 2008. Auditing and Assurance Services, Twelfth Edition. Terjemahan Herman Wibowo. Jakarta.

Badan Pemeriksa Keuangan RI. 2007. Peraturan Badan Pemeriksa Keuangan RI No. 1 Tahun 2007 tentang Standar Pemeriksaan Keuangan Negara. Jakarta : Badan Pemeriksa Keuangan RI

Bastian, Indra. 2010. Akuntansi Sektor Publik. Edisi Ketiga. Jakarta : Erlangga.

Bisri, Hasan. BPK RI dan Keterbukaan Informasi Publik.

Chi, W., dan H. Huang. 2005. Discretionary Accruals, Audit-Firm Tenure, and Audit-Partner Tenure: Empirical Evidence from Taiwan. Journal of Contemporary Accounting and Economics 1 (1): pg. 65-92.

COSO. 2000. COSO-Based Auditing. Penerjemah : Amin Widjaja. . Jakarta : Harvarindo.

Edison Emron, Anwar Yohny, Komariyah Imas, 2016. Manajemen Sumber Daya Manusia : Strategi dan Perubahan Dalam Rangka Meningkatkan Kinerja Pegawai dan Organisasi. Cetakan Kesatu. Bandung : Alfabeta

Hartanto, Rudy. 2015. Analisis Penyelesaian Tindak Lanjut Hasil Pemeriksaan BPK RI (Perspektif Karakteristik Auditee, Karakteristik Auditor BPK, Karakteristik Eksekutif dan Karakteristik Legislatif Daerah). Tesis. Universitas Sebelas Maret.

Hery. 2006. Pengaruh Pelaksanaan Etika Profesi Terhadap Pengambila Keputusan Akuntan Publik (Auditor). Media Riset Akuntansi, Auditing dan Informasi Vol.6, No.2, Agusutus 2006.

Ikatan Akuntan Indonesia, Standar Profesional Akuntan Publik per 1 Januari 2001, Salemba Empat, 2001.

Liu, J \& Lin, B. 2012. Government Auditing and Corruption Control: Evidence from China's Provincial Panel Data. China Journal Accounting Research, 5, 163-186.

Mardiasmo. 2004. Otonomi \& Manajemen Keuangan Daerah. Edisi II. Yogyakarta : Andi. . 2009. Akuntansi Sektor Publik. Edisi IV. Yogyakarta : Andi

Moeller, Robert. 2009. Brink"s Modern Internal Auditing: A Common Body of Knowledge, 7 th Edition. New York: John Wiley and Sons, Inc. 
Moon, M.Jae. 2000. Organization Commitment. Revisited in New Public Management: Motivation, Organizational Culture, Sector, and Managerial Level. Article in Public Performance \& Management Review 24(2):177. December 2000 with 53 Reads. DOI: 10.2307/3381267.

Mulyadi. 2002. Auditing I. Jakarta : Salemba Empat

Nasucha, Chaizi, 2004. Reformasi Administrasi Publik : Teori dan Praktik. Jakarta : Gramedia Widiasarana Indonesia.

Pemerintah Republik Indonesia. 2016. Peraturan Pemerintah Nomor 18 Tahun 2016 tentang Perangkat Daerah.

.Nomor 60 Tahun 2008 Tentang Sistem Pengendalian Intern Pemerintah

Purba, CB. 2014. Efektivitas Tindak Lanjut Hasil Pemeriksaan BPK Atas Laporan Keuangan Pemerintah Daerah Di Kalimantan Barat, Kalimantan Tengah, Dan Kalimantan Timur. Jurnal Akuntansi/Volume XVIII, No. 02, Mei 2014: 233-255.

Undang-Undang .Nomor 15 Tahun 2004 tentang Pemeriksaan Pengelolaan dan Tanggung Jawab Keuangan Negara.

Saleh, Rachmad dan Susilowati. 2004. Studi Empiris Ketepatan Waktu Pelaporan Keungan Perusahaan Manufaktur di Bursa Efek Jakarta. Jurnal Bisnis Strategi. Vol.13.h 67-80.

Santoso, U. dan Pambelum Y.J. 2008. Pengaruh Penerapan Akuntansi Sektor Publik Terhadap Akuntabilitas Kinerja Instansi Pemerintah Dalam Mencegah Fraud. Jurnal Administrasi Bisnis (2008), Vol.4, No.1: hal. 14-33, (ISSN:0216-1249) : Center for Business Studies. FISIP - Unpar.

Sawyer, B. Lawrence, Dittenhofer, Mortimer and James H. Scheiner. 2006. Sawyer's Internal Auditing. The Practice of Modern Internal Auditing. Diterjemahkan oleh : Desi Adhariani. Buku 2. Edisi 5. Jakarta : Salemba Empat.

Sidik Priadana, Management, Leadership \& Strategic (Materi pascasarjana UNPAS), 2012.

Setyaningrum, Dyah, Lindawati Gani dan Dwi Martani. 2014. Pengaruh Kualitas Auditor dan Pengawasan Legislatif terhadap Temuan Audit dengan Tindak Lanjut Rekomendasi Hasil Pemeriksaan Sebagai Variabel Intervening. SNA 17 Mataram, Lombok Universitas Mataram 24-27 Sept 2014.

Siagian P, Sondang. 2005. Fungsi-fungsi Manajerial, Edisi Revisi. Jakarta : Bumi Aksara.

Sopiah. 2008. Perilaku Organisasional. Jakarta : Salemba Empat.

Sugiyono. 2016. Metode Penelitian Kuantitatif, Kualitatif, dan R\&D. Cetakan ke-23. Bandung : Alfabeta.

Suryanto, Agus. 2015. Studi Keterlambatan Tindak Lanjut Temuan Hasil Pemeriksaan Inspektorat Daerah Kab. Kulonprogo D.I Yogyakarta dan Implementasi Manajerial. Prosiding Interdisciplinary Postgraduate Student Conference $1^{\text {st }}$ Program Pascasarjana Universitas Muhammadiyah Yogyakarta (PPs UMY) ISBN: 978-602-19568-2-3.

Tandiontong, Mathius. 2016. Kualitas Audit dan Pengukurannya. Bandung : Alfabeta.

Ulum, Miftahul. 2014. Faktor yang Mempengaruhi Kepatuhan Pendokumentasian Asuhan Keperawatan berdasarkan Teori Kepatuhan Milgram. Jurnal Administrasi Kesehatan Indonesia: Vol. 1-No.3/2014-03. TOC:7, and page: 252-262. 